pacemaker was working satisfactorily and there had been complete resolution of the pneumopericardium.

Three months later the patient presented with pleuritic chest pain and was admitted to hospital after a syncopal episode. She was found to be feverish and to have radiological evidence of both pericardial and pleural effusions. In addition the epicardial pacemaker was intermittently failing to capture. Postcardiotomy syndrome was diagnosed and, though aspirin resulted in rapid improvement of symptoms and of the pericardial and pleural effusions, the pacemaker continued to show intermittent failure to capture. In view of the syncopal episode a new permanent endocardial pacing system was inserted electively through a right cephalic vein cut-down, using a wedged electrode. Thereafter she made an uncomplicated recovery and was discharged home.

\section{Discussion}

In most cases effective permanent cardiac pacing may be established with a low incidence of complications. ${ }^{2-4}$ The common causes of early failure of endocardial pacing are poor positioning of the electrode initially and subsequent displacement. ${ }^{1}$ Less common but well recognised are perforation of the myocardium, fracture of the lead, infection, and failure of the generator. Temporary endocardial pacing in our patient resulted in a pneumopericardium. Presumably the electrode had penetrated not only the right ventricle but also the pericardium into the adjacent lung.
Pericarditis after epicardial pacing is a well-recognised complication. ${ }^{5}$ In our patient the early postoperative pericarditis was followed by recurrent attacks: these were thought to be due to the postcardiotomy syndrome as no infective, autoimmune, or other cause could be identified. The epicardial electrodes themselves, however, may result in focal inflammation and cause a relapsing pericarditis. ${ }^{5}$

\section{References}

1 Parsonnet V, Bilitch M, Furman S, et al. Early malfunction of transvenous pacemaker electrodes. A three centre study. Circulation 1979;60:590-6.

${ }^{2}$ Seremetis MG, de Guzman VC, Lyons WS, Peabody JW Jr. Cardiac pacemakers. Clinical experience with 289 patients. Am Heart $\mathcal{F} 1973$; $85: 739-48$.

${ }^{3}$ Davidson DM, Braak CA, Preston TA, Judge RD. Permanent ventricular pacing: effect on long term survival, congestive heart failure, and subsequent myocardial infarction and stroke. Ann Intern Med 1972; $76: 345-51$.

${ }^{4}$ Gould L, Reddy CVR, Maghazeh P, et al. Three hundred and fifty-three consecutive patients with permanent transvenous pacemakers. Pace $1980 ; 3: 452-5$.

5 Peters RW, Scheinman MM, Raskin S, Thomas AN. Unusual complications of epicardial pacemakers. Recurrent pericarditis, cardiac tamponade and pericardial constriction. Am f Cardiol 1980;45:1088-94.

(Accepted 26 fune 1981)

\title{
Pulmonary oedema without critical increase in left atrial pressure in acute myocardial infarction
}

\author{
A D TIMMIS, M B FOWLER, R J BURWOOD, P GISHEN, R VINCENT, D A CHAMBERLAIN
}

\begin{abstract}
Twelve patients with acute myocardial infarction and radiological evidence of pulmonary oedema were observed in whom the left atrial pressure, measured indirectly as pulmonary artery end-diastolic pressure, was not critically increased (range $5-12 \mathrm{~mm} \mathrm{Hg}$ with reference to sternal angle). Eight of the patients had been treated with frusemide, but only six had responded; hence in at least half of the series diuresis could not account for the anomalous finding.

Six patients with low cardiac output were given infusions to expand plasma volume. Appreciable increments in mean values for cardiac index (1.6 to $2.0 \mathrm{l} / \mathrm{min} /$ $\left.\mathrm{m}^{2}\right)$, stroke index $\left(18\right.$ to $23 \mathrm{ml} /$ beat $\left./ \mathrm{m}^{2}\right)$, mean arterial pressure (65 to $86 \mathrm{~mm} \mathrm{Hg}$ ), and pulmonary artery end-diastolic pressure ( 8 to $15 \mathrm{~mm} \mathrm{Hg}$ ) were recorded. This group, and the remaining six patients with higher cardiac output, survived to leave hospital.

Delay in radiographic clearing after a fall of left atrial pressure was a possible explanation for the rela-
\end{abstract}

Royal Sussex County Hospital, Brighton BN2 5BE

A D TIMMIS, MB, MRCP, cardiac registrar (present address: Department of Cardiology, Massachusetts General Hospital, Boston, Mass 02114, USA)

M B FOWLER, MB, MRCP, research registrar (present address: Department of Cardiology, King's College Hospital, London SE5)

R J BURWOOD, MD, FRCR, consultant radiologist

$R$ VINCENT, MB, MRCP, consultant cardiologist

D A CHAMBERLAIN, MD, FRCP, consultant cardiologist

King's College Hospital, London SE5 9RS

P GISHEN, MB, MRCR, consultant radiologist tively low pulmonary artery end-diastolic pressures, especially in the patients treated successfully with diuretics. Other mechanisms, such as alterations in pulmonary vascular permeability, might also have contributed to the syndrome.

Pulmonary oedema without a critical increase in the left atrial pressure is unusual in acute myocardial infarction but the therapeutic implications are important. Withdrawal of diuretics may be indicated, and in some cases expansion of plasma volume may lead to striking clinical improvement.

\section{Introduction}

Left ventricular failure in acute myocardial infarction is usually associated with an increase in left atrial pressure. As the pressure rises pulmonary venous dilatation, interstitial pulmonary oedema, and, finally, alveolar pulmonary oedema develop. ${ }^{1}$ These changes may be detected radiologically and provide a more reliable indication of left atrial pressure than do physical signs such as basal crepitations or added heart sounds. ${ }^{2}$ Thus the chest radiograph is widely used to assess diuretic requirements in acute myocardial infarction. ${ }^{3-5}$

In 1968 Nixon $^{6}$ described a patient with severe myocardial infarction and radiological signs of pulmonary oedema in whom the left atrial pressure was normal. Similar anomalous findings were later reported in other patients with infarction ${ }^{1}$ and cardiomyopathy. ${ }^{7}$ In such cases treatment with diuretics on the basis of the abnormal chest radiographs may further lower the left atrial pressure to the point at which cardiac output, by Starling's principle, is reduced. Recognising this small group of patients who have radiological evidence of pulmonary 
oedema without critical increases in the left atrial pressure is of great practical importance, since withdrawal of diuretics may be indicated; and in some cases striking clinical improvement may occur after plasma volume expansion.

In 14 months we observed 12 patients with acute myocardial infarction and refractory or severe pulmonary oedema in whom the indirect left atrial pressure was not critically raised. We therefore believe that this syndrome is uncommon but not rare and should be more widely recognised.

\section{Patients and methods}

The 12 patients were among a group of 74 who had had their pulmonary artery pressures monitored in the cardiac care unit at the Royal Sussex County Hospital from October 1978 to November 1979. Indications for pressure monitoring were pump failure judged severe enough to be life threatening and inadequate response to conventional treatment for failure. During the same period a total of 584 patients were admitted with myocardial infarction or coronary insufficiency.

Table I summarises the clinical data for the patients with lowpressure pulmonary oedema. They had an average age of 64 years and were admitted from 30 to 320 minutes (median 90 minutes) after the onset of chest pain. All had electrocardiographic evidence of acute myocardial infarction. One patient had a brief episode of ventricular tachycardia treated with lignocaine during transport to hospital in the resuscitation ambulance. The remainder were in stable rhythm: sinus rhythm in 10 and atrial fibrillation in one. Four patients had clinical evidence of low cardiac output when the study began, and two others had developed severe cardiogenic shock. Serum albumin concentration was normal in all patients. together with 12 other portable films, by an independent cardiac radiologist: only the radiographs from the 12 patients in this report were considered to show interstitial or alveolar pulmonary oedema.

Student's $t$ test for paired data was used for the statistical comparison of results.

\section{Results}

Despite the radiographic appearances the pulmonary artery enddiastolic pressure with reference to sternal angle was not critically increased in any of the patients; values ranged from 5 to $12 \mathrm{~mm} \mathrm{Hg}$ (mean $9 \mathrm{~mm} \mathrm{Hg}$ ). Table II gives the haemodynamic measurements in individual patients. The cardiac index was $2.01 / \mathrm{min} / \mathrm{m}^{2}$ or less in eight of the patients, six of whom had clinical signs of poor peripheral

TABLE II-Haemodynamic measurements (pressures measured with reference to sternal angle)

\begin{tabular}{|c|c|c|c|c|c|c|}
\hline Case no & $\begin{array}{l}\text { Heart rate } \\
\text { (beats } / \mathrm{min} \text { ) }\end{array}$ & $\begin{array}{c}\text { Mean } \\
\text { arterial } \\
\text { pressure } \\
(\mathrm{mm} \mathrm{Hg})\end{array}$ & $\begin{array}{c}\text { Mean } \\
\text { right } \\
\text { atrial } \\
\text { pressure } \\
(\mathrm{mm} \mathrm{Hg})\end{array}$ & $\begin{array}{c}\text { Pulmonary } \\
\text { artery } \\
\text { end-diastolic } \\
\text { pressure } \\
(\mathrm{mm} \mathrm{Hg})\end{array}$ & $\begin{array}{c}\text { Cardiac } \\
\text { index } \\
\left(1 / \mathrm{min} / \mathrm{m}^{2}\right)\end{array}$ & $\begin{array}{c}\text { Stroke } \\
\text { index } \\
\left(\mathrm{ml} / \text { beat } / \mathrm{m}^{2}\right)\end{array}$ \\
\hline 1 & 78 & 100 & -3 & 6 & 1.8 & 23 \\
\hline 2 & 100 & 78 & -5 & 12 & $2 \cdot 2$ & 22 \\
\hline 3 & 92 & 83 & -2 & 12 & 1.8 & 20 \\
\hline 4 & 96 & 71 & -2 & 10 & $2 \cdot 2$ & 23 \\
\hline 5 & 98 & 97 & -2 & 10 & 2.6 & 27 \\
\hline 6 & 68 & 140 & -2 & 9 & $2 \cdot 1$ & 31 \\
\hline 7 & 92 & 70 & -6 & 10 & $2 \cdot 0$ & 22 \\
\hline 8 & 102 & 110 & -3 & 10 & $1 \cdot 4$ & 14 \\
\hline 9 & 80 & 54 & 2 & 6 & 2.0 & 25 \\
\hline 10 & 70 & 65 & -4 & 7 & $1 \cdot 4$ & 20 \\
\hline 11 & 102 & 47 & -5 & 7 & 1.4 & 14 \\
\hline 12 & 98 & 45 & -6 & 5 & $1 \cdot 3$ & 13 \\
\hline
\end{tabular}

TABLE I-Clinical data for patients with low-pressure pulmonary oedema

\begin{tabular}{|c|c|c|c|c|c|c|c|}
\hline Case no & $\begin{array}{l}\text { Age (years) } \\
\text { and sex }\end{array}$ & $\begin{array}{c}\text { Time from onset } \\
\text { of pain to } \\
\text { admission (min) }\end{array}$ & $\begin{array}{c}\text { Site of } \\
\text { myocardial infarct }\end{array}$ & $\begin{array}{c}\text { Radiographic } \\
\text { pulmonary oedema }\end{array}$ & $\underset{\text { Initial }}{\text { treatment* }}$ & $\begin{array}{l}\text { Urinary response } \\
\text { to frusemide }\end{array}$ & $\begin{array}{l}\text { Treatment with } \\
\text { plasma volume } \\
\text { expander } \dagger\end{array}$ \\
\hline $\begin{array}{r}1 \\
2 \\
3 \\
4 \\
5 \\
6 \\
7 \\
8 \\
9 \\
10 \\
11 \\
12\end{array}$ & $\begin{array}{l}67 M \\
52 M \\
68 M \\
57 M \\
71 M \\
67 M \\
65 M \\
74 \mathrm{~F} \\
59 M \\
59 \mathrm{~F} \\
63 \mathrm{M} \\
63 \mathrm{M}\end{array}$ & $\begin{array}{r}35 \\
60 \\
180 \\
240 \\
60 \\
180 \\
90 \\
30 \\
240 \\
90 \\
320 \\
30\end{array}$ & $\begin{array}{l}\text { Anterior } \\
\text { Anterior } \\
\text { Anterior } \\
\text { Anterior } \\
\text { Anterior } \\
\text { Anterior } \\
\text { Inferior } \\
\text { Anterior } \\
\text { Inferior } \\
\text { Inferior } \\
\text { Inferior } \\
\text { Anterior }\end{array}$ & $\begin{array}{l}\text { Alveolar } \\
\text { Alveolar } \\
\text { Alveolar } \\
\text { Alveolar } \\
\text { Alveolar } \\
\text { Interstitial } \\
\text { Alveolar } \\
\text { Alveolar } \\
\text { Interstitial } \\
\text { Alveolar } \\
\text { Interstitial } \\
\text { Alveolar }\end{array}$ & $\begin{array}{l}\text { Frusemide } \\
\text { Frusemide } \\
\text { Frusemide } \\
\text { Frusemide } \\
\text { Digoxin } \\
\text { Frusemide }\end{array}$ & $\begin{array}{l}>80 \mathrm{ml} / \text { hour } \\
>80 \mathrm{ml} / \text { hour } \\
<30 \mathrm{ml} / \text { hour } \\
<30 \mathrm{ml} / \text { hour } \\
>80 \mathrm{ml} / \text { hour }\end{array}$ & $\begin{array}{l}0.9 \% \text { saline } 500 \mathrm{ml} \\
0.9 \% \text { saline } 400 \mathrm{ml} \\
\text { Haemaccel } 500 \mathrm{ml} \\
\text { Haemaccel } 700 \mathrm{ml} \\
\text { Haemaccel } 700 \mathrm{ml} \\
\text { Haemaccel } 1000 \mathrm{ml}\end{array}$ \\
\hline
\end{tabular}

* All patients sedated with diamorphine at time of admission.

+ Diuretics withdrawn in all patients after haemodynamic assessment.

On admission all patients had received diamorphine. Eight had been treated immediately with frusemide: six had responded with prompt diuresis, but no diuretic response was observed in the other two, whose urine output remained less than $30 \mathrm{ml} /$ hour. Four patients were given no diuretic treatment at all, and only one had received diuretics or opiates within the six hours before the study. Only the patient in atrial fibrillation was given digoxin.

Initial observations were made in the cardiac care unit between one and 72 hours (median eight hours) after admission. The radial artery was cannulated. Right heart pressures and cardiac output were measured using balloon-tipped catheters, as described. ${ }^{8}$

Subsequent management was guided by the haemodynamic measurements. None of the patients received further diuretic treatment for at least two days after completing the study. Six patients with low cardiac outputs were treated with infusions of isotonic saline (two patients) or polygeline and electrolytes (Haemaccel; four patients) until pulmonary artery diastolic pressure was about $15 \mathrm{~mm} \mathrm{Hg}$. Responses to treatment were monitored carefully. The purpose of the observations and infusions was explained to the patients, but we did not ask for written consent for the reasons outlined elsewhere. ${ }^{8}$

Interstitial or pulmonary oedema was diagnosed on portable chest radiographs (anteroposterior) taken within one hour of the haemodynamic measurements. The radiological assessment was confirmed by a consultant radiologist. The $x$-ray films were finally read blindly, perfusion. Eight patients were normotensive, but four were severely hypotensive with mean arterial pressures ranging from 45 to 65 $\mathrm{mm} \mathrm{Hg}$.

In every case pulmonary oedema cleared within 48 hours of the study without recourse to further diuretic treatment. The six patients with low cardiac output and signs of poor peripheral perfusion who were treated with infusions of isotonic saline or Haemaccel required an average of $650 \mathrm{ml}$ (range 400 to $1000 \mathrm{ml}$ ) to increase pulmonary arterial diastolic pressure to about $15 \mathrm{~mm} \mathrm{Hg}$. The figure shows the significant increment in mean cardiac index $\left(1.6\right.$ to $\left.2.01 / \mathrm{min} / \mathrm{m}^{2} ; \mathrm{p}<0.01\right)$, mean stroke index (18 to $23 \mathrm{ml} /$ beat $\left./ \mathrm{m}^{2} ; \mathrm{p}<0.005\right)$, mean blood pressure (65 to $86 \mathrm{~mm} \mathrm{Hg} ; \mathrm{p}<0.02$ ), and mean pulmonary artery enddiastolic pressure ( 8 to $15 \mathrm{~mm} \mathrm{Hg} ; \mathrm{p}<0.001$ ) resulting from the infusions. All the patients survived to leave hospital.

\section{Discussion}

Pulmonary oedema complicating acute myocardial infarction tends to develop when the indirectly measured left atrial pressure rises above $13 \mathrm{~mm} \mathrm{Hg}$ with reference to sternal angle (18 $\mathrm{mm} \mathrm{Hg}$ with reference to mid-chest). ${ }^{1}$ Unpublished observations in our unit confirm that a pulmonary artery end-diastolic pressure of $13 \mathrm{~mm} \mathrm{Hg}$ offers a fair plane of division between 

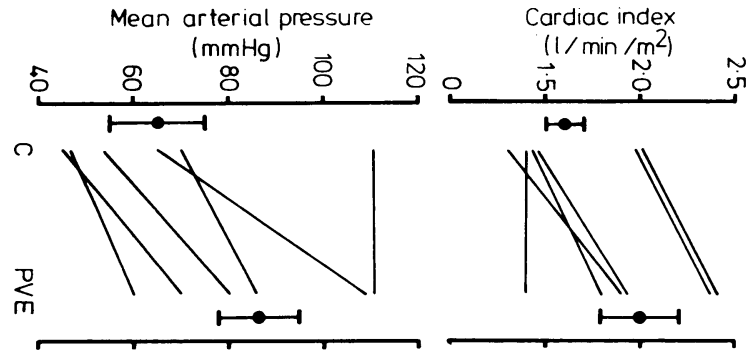

Pulmonary artery diastolic pressure $(\mathrm{mmHg})$

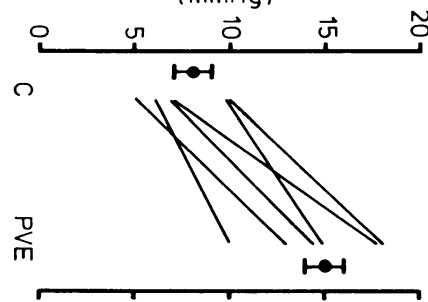

Stroke index Oे

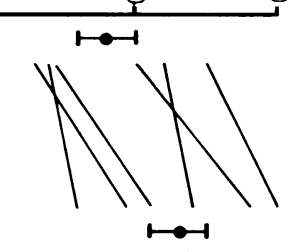

Haemodynamic responses to infusions of plasma volume expander in six patients with low-output states and radiographic pulmonary oedema. Points and bars are means \pm SEM. $C=$ Control values. $\mathrm{PVE}=\mathrm{Responses}$ to plasma volume expander.

patients with and without radiological evidence of pulmonary oedema. The patients in this report, however, represented important exceptions to this general rule: in each case the pulmonary artery end-diastolic pressure was less than $13 \mathrm{~mm} \mathrm{Hg}$ despite radiological evidence of pulmonary oedema.

In eight patients pulmonary oedema had failed to clear despite diuretics. Six of these patients had responded to frusemide with a prompt diuresis, and the low pulmonary artery enddiastolic pressures in this group could probably be explained, at least in part, by delayed resorption of fluid into the vascular space after falls in left atrial pressures-a "post-therapeutic phase lag."

The explanation for the four patients who had not received frusemide and for the two who did not respond with a diuresis may also be related to delayed resorption of oedema after a spontaneous fall in left ventricular filling pressure, though none showed any clinical evidence of improving haemodynamic function. A low cardiac output by itself must also lessen atrial filling, but myocardial dysfunction severe enough to influence forward flow is usually associated with increased filling pressure.

Other possible mechanisms, such as drug effects unrelated to diuresis, must also be considered, but the evidence that frusemide and opiates reduce left atrial pressure by influencing systemic venous tone ${ }^{910}$ in patients of this type has been challenged.11-13 It is doubtful that such activity was important in our patients, particularly since no drugs were given to 11 of them in the six hours before the haemodynamic study.

Causes of pulmonary oedema other than an increase in left atrial pressure also merit consideration. The serum albumin concentrations in our patients were normal, but membrane permeability also influences flow across the pulmonary capillary endothelium. ${ }^{14}$ Hypoxaemia and shock increase the permeability of the capillary membrane to protein ${ }^{15}$ with the result that pulmonary interstitial osmotic pressure rises. Thus alterations in the physical properties of the membrane may have contributed towards the development of pulmonary oedema at low left atrial pressures in those patients with low-output states and cardiogenic shock. In such patients increasing the cardiac output and pulmonary perfusion by expansion of plasma volume results in increased pulmonary lymphatic flow: the clearance of protein and water from the pulmonary interstitium may thereby be hastened.16 No single explanation is likely to account fully for low-pressure pulmonary oedema, and the pathogenesis may be complex.

The mechanism of low-pressure pulmonary oedema is less important than the clinical implications. Most doctors use chest radiography as a main guide to diuretic requirements. ${ }^{2}$ We have drawn attention to a small subgroup in whom the appearances may mislead. When cardiac output is adequate excess diuretics cause relatively little harm; but for patients with low cardiac output a further reduction in left ventricular filling pressure will precipitate or worsen cardiogenic shock. Expanding the plasma volume was probably life saving in our two patients with cardiogenic shock and resulted in rapid clinical improvement in four others. Only relatively small volumes of infused fluid were needed to produce appreciable alterations in filling pressure. Careful pressure monitoring during infusion is therefore important. The initial use of $5 \%$ dextrose administered very rapidly provides a useful therapeutic test; little harm can result because this solution quickly diffuses throughout the total body fluid.

We recommend that the management of left ventricular failure complicating myocardial infarction should be guided by the indirect measurement of left atrial pressure if pulmonary oedema fails to improve within a few hours of conventional treatment, particularly in the presence of low-output states. Values above $13 \mathrm{~mm} \mathrm{Hg}$, with reference to sternal angle, indicate the need for further diuretic treatment or the introduction of additional agents such as digitalis and vasodilators. If the pulmonary artery end-diastolic pressure is less than $13 \mathrm{~mm} \mathrm{Hg}$, however, further plasma volume depletion is unlikely to be beneficial and may be dangerous. Diuretics should be withdrawn, at least temporarily, and if cardiac output is critically reduced infusions of plasma volume expander may result in striking clinical improvement.

We thank Professor Desmond Julian for helpful criticisms of the draft manuscript.

\section{References}

${ }^{1}$ McHugh TJ, Forrester JS, Adler L, Zion D, Swan HJC. Pulmonary vascular congestion in acute myocardial infarction: hemodynamic and radiologic correlations. Ann Intern Med 1972;76:29-33.

2 Lassers BW, George M, Anderton JL, Higgins MR, Philp T. Left ventricular failure in acute myocardial infarction. Am $\mathcal{F}$ Cardiol 1970;25: 511-22.

3 Tattersfield AE, McNicol MW, Shawdon H, Rolfe D. Chest x-ray film in acute myocardial infarction. Br Med F 1969;ii:332-5.

4 Harrison BM, Conte PJ, Heitzman ER. Radiological detection of clinically occult cardiac failure following myocardial infarction. Br $\mathcal{F}$ Radiol 1971; 44:265-72.

5 Chait A, Cohen HE, Meltzer LE, Van Durme JP. The bedside chest radiograph in the evaluation of incipient heart failure. Radiology 1972; $105: 563-6$.

${ }^{6}$ Nixon PG. Pulmonary oedema with low left ventricular diastolic pressure in acute myocardial infarction. Lancet 1968;ii:146-7.

${ }^{7}$ Figueras J, Weil MH. Hypovolemia and hypotension complicating management of acute cardiogenic pulmonary edema. Am f Cardiol 1979; 44:1349-55.

8 Timmis AD, Strak SK, Chamberlain DA. Haemodynamic effects of salbutamol in patients with acute myocardial infarction and severe left ventricular dysfunction. $\mathrm{Br} \mathrm{Med} \mathcal{F}$ 1979;ii:1101-3.

- Dikshit K, Vyden JK, Forrester JS, Chatterjee K, Prakash R, Swan HJC. Renal and extrarenal hemodynamic effects of furosemide in congestive heart failure after acute myocardial infarction. $N$ Engl F Med 1973;288: 1087-90.

10 Vasko JS, Henney RP, Oldham HN, Brawley PK, Morrow AG. Mechanisms of action of morphine in the treatment of experimental pulmonary edema. Am 7 Cardiol $1966 ; 18: 876-83$.

11 Hesse B, Nielsen I, Lund-Jacobsen H. The early effects of intravenous frusemide on central haemodynamics, venous tone and plasma renin activity. Clin Sci Mol Med 1975;49:551-5.

12 Vismara LA, Leaman DM, Zelis R. The effects of morphine on venous tone in patients with acute pulmonary edema. Circulation 1976;54:335-7.

13 Timmis AD, Rothman MT, Henderson MA, Geal PW, Chamberlain DA. Haemodynamic effects of intravenous morphine in patients with acute myocardial infarction complicated by severe left ventricular failure. $\mathrm{Br}$ Med F 1980;280:980-2.

14 Starling EH. On the absorption of fluid from the connective tissue spaces. 7 Physiol (Lond) 1896;19:312-26.

15 Robin ED, Cross CE, Zelis R. Pulmonary edema. N Engl F Med 1973;288: 292-304.

16 Lauweryns JM, Baert JH. Alveolar clearance and the role of the pulmonary lymphatics. Am Rev Respir Dis 1977;115:625-83.

(Accepted 25 fune 1981) 